\title{
IMPLEMENTASI QUALITY FUNCTION DEPLOYMENT (QFD) UNTUK MENINGKATKAN LAYANAN PUBLIK DI RSUD KABUPATEN BULELENG BALI
}

\author{
${ }^{1}$ Gede Putu Agus Jana Susila, ${ }^{2} \mathrm{Ni}$ Nyoman Yulianthini, ${ }^{3} \mathrm{Ni}$ Luh Henny \\ Andayani \\ 1,2Jurusan Managemen, ${ }^{3}$ Jurusan Perhotelan, Fakultas Ekonomi dan Bisnis \\ Universitas Pendidikan Ganesha Singaraja-Bali
}

e-mail: janos_undiksha@yahoo.com

\begin{abstract}
Abstrak
Rumah sakit sebagai salah satu sarana kesehatan yang memberikan pelayanan kesehatan kepada masyarakat memiliki peran yang sangat strategis dalam mempercepat peningkatan derajat kesehatan masyarakat. Oleh karena itu, rumah sakit dituntut untuk memberikan pelayanan yang bermutu sesuai dengan standar yang ditetapkan dan dapat menjangkau seluruh lapisan masyarakat. Kepuasan pasien menjadi tolak ukur tingkat kualitas pelayanan kesehatan. Selain itu, kepuasan pasien merupakan satu elemen yang penting dalam mengevaluasi kualitas layanan dengan mengukur sejauh mana respon pasien setelah menerima jasa. Penelitian ini menggunakan analisis metode Quality Function Deployment untuk mengetahui atribut-atribut kepuasan yang diinginkan pasien, tingkat kepentingan, parameter teknik, kebutuhan proses dan prosedur kualitas. QFD diaplikasikan untuk menerjemahkan apa yang diinginkan oleh pasien ke dalam prosedur kualitas yang lebih terperinci. Hasil dari penelitian pada RSUD Kabupaten Buleleng dengan menggunakan QFD, didapatkan atribut-atribut kepuasan yang diinginkan oleh pasien dan diterjemahkan ke dalam parameter teknik dalam House of Quality (HOQ). Atribut-atribut yang merupakan prioritas untuk diperhatikan dan dipenuhi oleh pengelola RSUD Kabupaten Buleleng berdasarkan pembobotan dari masing-masing atribut tersebut, yaitu: ruang rawat inap yang bersih, tempat tidur yang nyaman, kamar mandi yang bersih, tempat ibadah yang bersih, ruang rawat inap yang sejuk dan tenang, ruang parkir yang aman dan memadai, jaminan peralatan medis yang steril, pelayanan yang cepat dan akurat, tenaga medis yang profesional dan ruang parkir yang memadai dan aman.
\end{abstract}

Kata kunci : Kebutuhan Pasien, QFD, HOQ

\begin{abstract}
Hospital as one of the health facilities that provide health services to the community has a very strategic role in accelerating the improvement of public health. Therefore, hospitals are required to provide quality services in accordance with established standards and can reach all levels of society. Patient satisfaction became a proxy for the quality of health care. In addition, patient satisfaction is an important element in evaluating service quality by measuring the extent to which
\end{abstract}


the response of patients after receiving services. This study uses analysis of Quality Function Deployment method to determine the attributes desired patient satisfaction, level of interest, technical parameters, the need for quality processes and procedures. QFD was applied to translate what is desired by the patient into a more detailed quality procedures. Results of research on Buleleng Regency Hospital using QFD, obtained satisfaction attributes desired by the patient and translate into technical parameters in the House of Quality (HOQ). Attributes that are considered a priority for managers of hospitals and met by Buleleng regency based weighting of each of these attributes, namely: inpatient rooms are clean, comfortable beds, clean bathrooms, clean place of worship, inpatient wards cool, calm, secure parking space and adequate assurance of sterile medical devices, fast and accurate service, professional medical personnel and adequate parking space and safe.

Keywords: Patient needs, QFD, HOQ.

\section{LATAR BELAKANG}

Rumah sakit sebagai salah satu sarana kesehatan yang memberikan pelayanan kesehatan kepada masyarakat memiliki peran yang sangat strategis dalam mempercepat peningkatan derajat kesehatan masyarakat. Oleh karena itu, rumah sakit dituntut untuk memberikan pelayanan yang bermutu sesuai dengan standar yang ditetapkan dan dapat menjangkau seluruh lapisan masyarakat. Menurut Azwar (1996), pelayanan kesehatan yang bermutu adalah pelayanan kesehatan yang dapat memuaskan setiap pemakai jasa layanan yang sesuai dengan tingkat kepuasan rata-rata penduduk serta penyelenggaraannya sesuai dengan standart dan kode etik profesi yang telah ditetapkan. Sehubungan dengan hal itu, Pemerintah juga mengeluarkan peraturan melalui Keputusan Menteri Kesehatan RI No.129/MenKes/SK/II/ 2008 tentang Standar Pelayanan Minimal Rumah Sakit, pedoman organisasi rumah sakit umum, bagaimana pengoperasiannya sebagai pelayanan jasa organisasi publik yang baik terhadap masyarakat. Peraturan tersebut dikeluarkan guna mewujudkan standar pelayanan kesehatan yang baik di rumah sakit secara merata di setiap daerah.

$$
\text { Bendall-Lyon }
$$
mengevalusi struktur dan komponen kepuasan pasien terhadap pelayanan di rumah sakit. Mereka mendefinisikan struktur pelayanan sebagai lingkungan dan fasilitas secara fisik dimana pelayanan tersebut diberikan. Kepuasan ditunjukkan oleh sikap pasien setelah menerima pelayanan medis dari pihak rumah sakit. Jika pasien merasa pelayanan yang diberikan sesuai dengan harapannya, maka biasanya akan memberitahukan sistem pelayanan yang diperoleh ke orang lain yang dikenalinya. Kepuasan pasien direlasikan sebagai bentuk kepuasan secara menyeluruh dengan tujuan untuk merekomendasikan rumah sakit tersebut kepada orang lain (word of mouth). Selain itu, kepuasan juga dihubungkan dengan perilaku pasien yang akan membandingkan pengalaman terhadap harapan yang diinginkan atau membandingkannya 
dengan pelayanan yang diberikan dari pihak rumah sakit. RSUD Kabupaten Buleleng berusaha agar apa yang dibutuhkan oleh pelanggannya dapat dipenuhi dengan baik dan memahami apa yang diinginkan oleh pasien sebagai customer, serta melihat kemampuan yang di miliki dalam proses pemenuhan kebutuhan tersebut. Salah satu cara dalam mengubah harapan konsumen ke dalam persyaratanpersyaratan layanan jasa yang sesuai adalah dengan menggunakan Quality Function Deployment (QFD). Fokus utama dari QFD adalah melibatkan pelanggan pada proses pengembangan produk sedini mungkin. QFD memungkinkan organisasi untuk memprioritaskan kebutuhan pelanggan, menemukan tanggapan inovatif terhadap kebutuhan tersebut, dan memperbaiki proses hingga tercapai efektivitas maksimum. Kelebihan dari QFD adalah dapat mengurangi waktu desain sebesar $40 \%$ dan biaya desain sebesar $60 \%$ secara bersamaan dengan dipertahankan dan ditingkatkannya kualitas desain. Selain itu ada beberapa manfaat yang dapat diperoleh dari QFD yaitu fokus pada pelanggan, efisiensi waktu, orientasi pada kerjasama tim, dan orientasi pada dokumentasi (Tjiptono, 2003).

\section{METODE PENELITIAN \\ Metode Pengumpulan Data}

Metode yang digunakan dalam pengumpulan data adalah:

a. Metode Interview

Adalah metode pengumpulan data dengan cara mengadakan Interview secara langsung dengan responden yang bersangkutan untuk memperoleh data yang diperlukan sesuai dengan penelitian yang diangkat.

b. Metode Observasi

Adalah metode pengumpulan data dengan cara mengadakan pengamatan dan pencatatan secara langsung pada objek penelitian untuk mendapatkan data serta informasi yang dibutuhkan dalam penelitian.

c. Dokumentasi

Adalah metode pengumpulan data yang diperoleh dengan menggunakan dokumen atau datadata yang telah lalu bersumber pada suatu instansi atau perusahaan guna mendapatkan data yang relevan dalam penelitian.

d. Studi Pustaka

Yaitu metode pengumpulan data dari buku-buku literatur yang berhubungan dengan masalahmasalah yang dibahas.

e. Penyebaran Angket (Kuesioner)

Metode pengumpulan data yang dilakukan dengan penyebaran angket atau kuesioner kepada responden yang diharapkan akan mendapatkan jawaban seperti yang diinginkan serta merespon keluhan ataupun masukan dari responden.

\section{Identifikasi Variabel Penelitian}

Proses identifikasi awal variabel penelitian dilakukan untuk mengetahui variabel-variabel apa yang akan digunakan dalam penelitian ini, dilakukan berdasarkan proses wawancara dan penggunaan studi literatur (buku-buku) sebagai pembanding. Dalam proses identifikasi variabel ini, garis besar atau acuan yang dipakai untuk menurunkan variabel penelitian didapat dari 5 dimensi utama 
servqual yang telah dikembangkan oleh Berry et all (dalam Tjiptono 2004).

Alasan penggunaan dimensi kualitas ini dipandang telah mewakili keseluruhan dimensi jasa baik yang bersifat teknis, yaitu segala bentuk fisik yang dihasilkan melalui proses jasa maupun dari sisi fungsional, yang merupakan cara atau proses konsumen menerima jasa yang diberikan. Dimensi kualitas jasa yang digunakan dalam pengukuran kualitas jasa ini, yaitu:

1. Bukti langsung (tangibles), meliputi fasilitas fisik, perlengkapan, pegawai, dan sarana komunikasi.

2. Keandalan (reliability), yakni kemampuan memberikan pelayanan yang dijanjikan dengan segera, akurat, dan memuaskan.

3. Daya tanggap (responsiveness), yaitu keinginan para staf untuk membantu para pelanggan dan memberikan pelayanan dengan tanggap.

4. Jaminan (assurance), mencakup pengetahuan, kemampuan, kesopanan, dan sifat dapat dipercaya yang dimiliki para staff, bebas dari bahaya, risiko atau keragu-raguan.

5. Empati, meliputi kemudahan dalam melakukan hubungan, komunikasi yang baik, perhatian pribadi, dan memahami kebutuhan para pelanggan.

\section{Penentuan Sampel}

Sampel adalah sebagian atau wakil populasi (Arikunto, 2002). Penentuan sampel dalam penelitian ini dengan menggunakan metode Accidental Sampling yaitu penentuan sampel berdasarkan responden yang ditemui pada saat penelitian dilakukan untuk mempermudah sampling. Jumlah sampel ditentukan sebanyak 150 responden agar sampel memiliki ciri-ciri yang esensial dari populasi dan dapat dianggap cukup representative.

\section{Penyusunan Kuesioner}

Penyusunan

kuesioner merupakan hal yang pokok untuk pengumpulan data. Tujuan pokok penyusunan kuesioner adalah untuk memperoleh informasi yang relevan dengan tujuan survai dan untuk memperoleh informasi dengan validitas dan reliabilitas setinggi mungkin (Singarimbun, 1989:175). Setelah mengidentifikasi kebutuhan konsumen, maka dilakukan penyusunan kuesioner dari hasil wawancara dan penentuan responden untuk menjawab kuesioner.

Untuk penyusunan kuesioner dilakukan melalui dua tahap, yaitu tahap awal dan tahap akhir. Tahap awal merupakan tahap penyusunan kuesioner berdasarkan kebutuhan konsumen yang ada. Teknik pengumpulan data dengan memberikan sejumlah pertanyaan kepada narasumber. Sedangkan daftar pertanyaan yang diberikan adalah dalam bentuk angket dengan pilihan jawaban yang tiap poin angka mempunyai beberapa tingkat arti kepentingan yang berbeda. Untuk menentukan tingkat kepentingan konsumen, kuesioner ini menggunakan skala Likert yang dimodifikasikan sebagai berikut :

1. Sangat Tidak Penting (STP) diberi bobot 1

2. Tidak Penting (TP) diberi bobot 2

3. Cukup Penting (CP) diberi bobot 3

4. Penting $(P)$ diberi bobot 4

5. Sangat Penting (SP) diberi bobot 5 
Setelah penyusunan kuesioner awal, dilakukan penyebaran kuesioner kepada responden dengan jumlah responden sebanyak 150 responden. Teknik pengambilan sampel untuk responden dalam penelitian ini adalah random sampling, yaitu suatu teknik mengambil individu untuk sampel dari populasi dengan cara random. Suatu cara disebut random jika tiap-tiap individu dalam populasi diberi kesempatan yang sama untuk ditugaskan menjadi anggota sampel. Namun demikian yang digunakan harus memenuhi karakteristik seperti yang telah ditentukan oleh peneliti. Setelah dilakukan penyebaran kuesioner awal sebanyak 30 responden kemudian dilakukan uji validitas dan reliabilitas data, sebelum dilakukan penyebaran kuesioner akhir.

1. Uji Validitas

Validitas menunjukkan sejauh mana suatu alat pengukur itu mengukur apa yang ingin diukur atau bisa digunakan untuk mengukur valid atau tidaknya suatu kuesioner. Suatu kuesioner dikatakan valid jika kuesioner yang disusun dapat mengukur apa yang ingin diukurnya (Sugiyono,2005). Hasil penelitian yang valid bila terdapat kesamaan antara data yang terkumpul dengan data yang sesungguhnya terjadi pada objek yang diteliti. Validitas suatu kuesioner dinyatakan dengan tingkat kemampuan butir-butir pernyataan dalam kuesioner tersebut dengan menggunakan program SPSS 12.0. Kemudian menguji taraf signifikan korelasi yaitu menguji signifikan $r$ yaitu sebagai berikut:

$r$ hasil $\geq r$ tabel, maka pertanyaan valid $r$ hasil $\leq r$ tabel, maka pertanyaan tidak valid

2. Uji Reliabilitas

Reliabilitas adalah indeks yang menunjukkan sejauh mana suatu alat pengukur dapat dipercaya atau dapat diandalkan. Bila suatu alat pengukur dipakai dua kali untuk mengukur gejala yang sama dan hasil pengukuran yang diperoleh relatif konsisten, maka alat pengukur tersebut reliabel. Dengan kata lain, reliabilitas menunjukkan konsistensi suatu alat pengukur di dalam mengukur gejala yang sama.

Untuk memudahkan dalam melakukan perhitungan validitas dan reliabilitas, maka pengujian ini dilakukan dengan menggunakan bantuan program SPSS 12.0 dimana hasil perhitungannya dikonsultasikan dengan harga rtabel pada taraf signifikansi $5 \%$. Bila rhasil > rtabel maka butir tersebut valid dan bila ralpha > rtabel maka butir tersebut reliabel.

Setelah dilakukan uji validitas dan reliabilitas, dilanjutkan dengan penyusunan kuesioner akhir dengan menghilangkan faktor-faktor dari kebutuhan konsumen yang dianggap tidak valid. Dalam kuesioner ini selain menentukan tingkat kepentingan konsumen, juga menentukan tingkat kepuasan konsumen yang diukur dengan menggunakan metode skala Likert yang dimodifikasikan sebagai berikut :

1. Tidak Baik (TB) diberi bobot 1

2. Kurang Baik (KB) diberi bobot 2

3. Cukup Baik (CB) diberi bobot 3

4. Baik (B) diberi bobot 4

5. Sangat Baik (SB) diberi bobot 5

Setelah penyusunan kuesioner akhir, dilakukan lagi penyebaran 
kuesioner dengan jumlah responden yang telah ditentukan oleh peneliti.

TAHAP PENGOLAHAN DATA

\section{Penerapan Quality Function Deployment (QFD)}

Tahap selanjutnya yaitu penerapan Quality Function Deployment (QFD) dilakukan dengan langkahlangkah sebagai berikut :

1. Mengidentifikasi kebutuhan konsumen

Mengidentifikasi kebutuhan konsumen, keinginan dan kebutuhannya adalah tahap awal dari Quality Function Deployment (QFD).

2. Membuat matriks perencanaan (Planning Matrix)

Matrik perencanaan berisi :

a. Tingkat kepentingan konsumen (Importance to Customer)

Penentuan tingkat kepentingan konsumen digunakan untuk mengetahui sejauh mana konsumen memberikan penilaian atau harapan dari kebutuhan konsumen yang ada.

b. Pengukuran tingkat kepuasan konsumen terhadap produk (Current Satisfaction Performance) Pengukuran tingkat kepuasan konsumen terhadap produk dimaksudkan untuk mengukur bagaimana tingkat kepuasan konsumen setelah pemakaian produk yang akan dianalisa.

c. Target (Goal)

Nilai target ini ditentukan oleh pihak perusahaan untuk mewujudkan tingkat kepuasan yang diinginkan oleh konsumen.

d. Rasio perbaikan (Improvement Ratio)
Rasio perbaikan merupakan perbandingan antara nilai yang diharapkan pihak perusahaan dengan tingkat kepuasan konsumen terhadap suatu produk.

e. Titik jual (Sales Point)

Titik jual adalah kontribusi suatu kebutuhan konsumen terhadap daya jual produk.

f. Raw weight

Raw Weight merupakan nilai keseluruhan dari data-data yang dimasukkan dalam Planning matrix tiap kebutuhan konsumen untuk proses perbaikan selanjutnya dalam upaya pengembangan produk.

g. Normalized raw weight

Normalized Raw Weight merupakan nilai dari Raw Weight yang dibuat dalam skala antara 0 - 1 atau dibuat dalam bentuk persentase.

3. Penyusunan kepentingan teknik Pada tahap ini perusahaan mengidentifikasi kebutuhan teknik yang sesuai dengan keinginan dan kebutuhan konsumen. Hal ini memberikan respon teknik untuk setiap keinginan dan kebutuhan konsumen yang dibutuhkan konsumen. Keadaan ini menunjukkan bagaimana perusahaan akan memberikan respons terhadap apa yang diinginkan konsumen.

4. Penentuan hubungan antara kebutuhan konsumen dengan kepentingan teknik

Penentuan ini menunjukkan hubungan antara setiap kebutuhan konsumen dan kepentingan teknik.

5. Penentuan prioritas 
Penentuan ini menunjukkan prioritas yang akan dikembangkan lebih dulu berdasarkan kepentingan teknik.

\section{TAHAP ANALISIS DATA DAN INTERPRETASI HASIL ANALISIS DATA}

Tahap ini adalah menganalisis dan interpretasi hasil dari pengolahan data yang diharapkan memberikan suatu hasil dari identifikasi faktor-faktor yang menjadi prioritas untuk pengembangan dan peningkatan kualitas pelayanan di RSUD Kabupaten Buleleng yang sesuai dengan kebutuhan dan keinginan pasien serta sesuai dengan kemampuan RSUD Kabupaten Buleleng dari hasil QFD.

\section{PENGUMPULAN DAN PENGOLAHAN DATA Penyusunan Atribut Penelitian}

Merumuskan atribut RSUD

Kabupaten Buleleng selain berasal dari kebutuhan dan keinginan pasien juga observasi dan wawancara dengan pihak pengelola sebagai informasi tambahan, sehingga semua customer requirement dapat teridentifikasi. Atribut penelitian yang berhasil dirumuskan ada 30 atribut. Pengkategorikan atribut penelitian tersebut dalam lima dimensi menurut Parasuraman (Tjiptono, 2003), yaitu 1) tangibles, meliputi fasilitas fisik, perlengkapan, pegawai, dan sarana komunikasi; 2) reliabilty, kemampuan memberikan pelayanan yang dijanjikan dengan segera, akurat, dan memuaskan; 3) responsiveness, yaitu keinginan para staf untuk membantu para pelanggan dan memberikan pelayanan dengan tanggap; 4) assurance, yakni kemampuan, kesopanan, dan sifat dapat dipercaya; dan 5) emphati, meliputi kemudahan dalam melakukan hubungan, komunikasi yang baik, perhatian pribadi, dan memahami kebutuhan para pelanggan.

\section{Analisis Terhadap Matrik Perencanaan}

Matrik perencanaan merupakan matrik yang berisi tentang tingkat kepentingan pengunjung (important to customer), tingkat kepuasan pengunjung (customer satisfaction performance), goal, improvement ratio, raw weight, normalized raw weight, cumulative normalized raw weight. Perhitungan dan analisis ini menghasilkan atribut-atribut yang merupakan prioritas untuk diperhatikan dan dipenuhi oleh pengelola RSUD Kabupaten Buleleng berdasarkan pembobotan dari masingmasing atribut tersebut, yaitu:

1. Ruang rawat inap yang bersih,

Dilihat dari besarnya nilai raw weight, atribut ini mempunyai nilai yang terbesar yaitu 9.868 dan normalized raw weight sebesar $4,6 \%$. $\mathrm{Hal}$ ini menunjukkan ruang rawat inap yang bersih mempunyai nilai tingkat kepentingan secara keseluruhan sebesar $4,6 \%$ dari seluruh keinginan dan kebutuhan pasien sehingga atribut ini memiliki prioritas pertama mengenai keinginan dan kebutuhan pasien yang harus dipenuhi. Karakter teknis yang berperan pada atribut ini yaitu pelayanan cleaning service. Pelayanan cleaning service ini memiliki hubungan positif dengan karakteristik penambahan lemari dan rak. Penambahan lemari dan rak, barang-barang dan perabotan pasien 
akan diletakkan di lemari dan rak. Kebersihan dan kerapian kamar pasien akan terjaga. Karakter teknis ini berperan besar untuk memenuhi atribut atau kebutuhan pasien yaitu ruang rawat inap yang bersih dengan nilai numerik 9. Nilai kepentingan teknik relatif dari karakteristik teknis ini adalah $8.61 \%$ dalam memenuhi kebutuhan pasien secara keseluruhan. Target dari karakteristik teknis ini adalah agar kebersihan dan kesehatan lingkungan terjaga. Karakteristik ini harus ditingkatkan agar target yang diharapkan tercapai. Rumah Sakit dapat meningkatkan karakteristik teknik pelayanan cleaning service dengan cara menambah petugas cleaning service dengan sistem kontrak

2. Tempat tidur yang nyaman,

Tempat tidur yang nyaman mempunyai nilai raw weight terbesar kedua yaitu 9.783 dan normalized raw weight sebesar $4,6 \%$. Hal ini menunjukkan tempat tidur yang bersih dan nyaman mempunyai nilai tingkat kepentingan secara keseluruhan sebesar $4,6 \%$ dari seluruh keinginan dan kebutuhan pasien. Tempat tidur yang nyaman memiliki prioritas kedua dalam keinginan dan kebutuhan pasien yang harus dipenuhi. Karakter teknis yang berperan pada atribut ini yaitu penambahan bed hidrolik dalam mewujudkan kenyamanan. Karakter teknis ini berperan untuk memenuhi atribut atau kebutuhan pasien yaitu tempat tidur yang nyaman dengan nilai numerik 9. Nilai kepentingan teknik relatif dari karakteristik teknis ini adalah $4.28 \%$ dalam memenuhi kebutuhan pasien secara keseluruhan. Target dari karakteristik teknis ini adalah agar fleksibilitas pasien terpenuhi. Pasien dalam pemeriksaan memerlukan kemudahan posisi agar memudahkan pemeriksaan. Demikian juga pasien setelah melahirkan maka akan sedikit mengalami keterbatasan dalam bergerak. Penambahan bed hidrolik, kebutuhan pasien tersebut diharapkan akan teratasi. Karakteristik ini harus ditingkatkan agar target yang diharapkan tercapai.

3. Kamar mandi yang bersih,

Kamar mandi yang bersih mempunyai nilai raw weight sebesar 9.470 dan normalized raw weight sebesar $4,5 \%$. Hal ini menunjukkan kamar mandi yang bersih mempunyai nilai tingkat kepentingan secara keseluruhan sebesar $4,5 \%$ dari seluruh keinginan dan kebutuhan pasien. Kamar mandi yang bersih menduduki prioritas ketiga dalam keinginan dan kebutuhan pasien yang harus dipenuhi. Karakter teknis yang berperan pada atribut ini yaitu pelayanan cleaning service. Karakter teknis ini berperan besar untuk memenuhi atribut atau kebutuhan pasien yaitu tersedianya kamar mandi yang bersih dengan nilai numerik 9. Nilai kepentingan teknik relatif dari karakteristik teknis ini adalah $8.61 \%$ dalam memenuhi kebutuhan pasien secara keseluruhan. Karakteristik ini harus ditingkatkan agar target yang diharapkan tercapai. Target dari karakteristik teknis ini adalah agar kebersihan dan kesehatan lingkungan terjaga. RSUD Kabupaten 
Buleleng harus dapat meningkatkan karakteristik teknik ini agar target yang diharapkan dapat tercapai. Dalam hal ini Rumah bersalin mampu meningkatkan karakteristik teknik pelayanan cleaning service dengan cara menambah petugas cleaning service dengan sistem kontrak

4. Tersedianya tempat ibadah yang bersih dan tenang

Tersedianya tempat ibadah yang bersih dan tenang mempunyai nilai raw weight sebesar 9.282 dan normalized raw weight sebesar $4.4 \%$. Hal ini menunjukkan tersedianya tempat ibadah yang bersih dan tenang mempunyai nilai tingkat kepentingan secara keseluruhan sebesar $4,4 \%$ dari seluruh keinginan dan kebutuhan pasien. Tersedianya tempat ibadah yang bersih dan tenang memiliki prioritas keempat dalam keinginan dan kebutuhan pasien yang harus dipenuhi. Karakter teknis yang berperan pada atribut ini yaitu fasilitas mushola dan pelayanan cleaning service. Karakter teknis ini berperan besar untuk memenuhi atribut atau kebutuhan pasien yaitu tersedianya tempat ibadah yang bersih dan tenang dengan nilai numerik 9. Adanya fasilitas tempat ibadah akan menjadikan pasien dan keluarganya merasa tenang dengan mendekatkan diri kepada Sang Pencipta. Karakter teknis ini memiliki hubungan positif dengan karakteristik pelayanan cleaning service. Nilai kepentingan teknik relatif dari karakteristik teknis ini adalah $2.68 \%$ dalam memenuhi kebutuhan pasien secara keseluruhan.
Target dari karakteristik teknis ini adalah kedamaian hati dan rohani tercapai. Rumah sakit mampu meningkatkan karakteristik teknik ini dengan cara petugas cleaning service yang saat ini sudah ada tetap dimanfaatkan dengan pihak rumah bersalin selalu mengecek kebersihan tempat ibadah.

5. Adanya jaminan peralatan medis yang steril

Adanya jaminan peralatan medis yang steril memiliki prioritas kelima dalam keinginan dan kebutuhan pasien yang harus dipenuhi. Karakter teknis yang berperan pada atribut ini yaitu fasilitas sterilisator. Fasilitas sterilisator dimaksudkan untuk mensterilkan peralatan sehabis digunakan. Dengan adanya sterilisator maka pasien merasa aman karena adanya jaminan peralatan yang steril. Karakter ini juga untuk memenuhi keinginan agar semua tindakan medis sesuai dengan prosedur, dan adanya jaminan dalam pelayanan. Nilai kepentingan teknik relatif dari karakteristik teknis ini adalah $6.45 \%$ dalam memenuhi kebutuhan pasien secara keseluruhan.

6. Ruang rawat inap yang sejuk dan tenang

Ruang rawat inap yang sejuk dan tenang mempunyai nilai raw weight sebesar 9.131 dan normalized raw weight sebesar $4.3 \%$. Hal ini menunjukkan ruang rawat inap yang sejuk dan tenang mempunyai nilai tingkat kepentingan secara keseluruhan sebesar $4.3 \%$ dari 
seluruh keinginan dan kebutuhan pasien. Ruang rawat inap yang sejuk dan tenang memiliki prioritas keenam dalam keinginan dan kebutuhan pasien yang harus dipenuhi. Karakter teknis yang berperan pada atribut ini yaitu penambahan fasilitas AC. Dengan adanya fasilitas AC akan bisa menambah kenyamanan ruang dan pasien bisa mengatur kondisi tempat dan suhu yang diinginkan. Karakter teknis ini berperan besar untuk memenuhi atribut tersedianya AC dalam kamar dengan nilai numerik 9. Karakteristik teknis ini juga untuk memenuhi atribut atau kebutuhan pasien ruang rawat inap yang sejuk dan tenang. Nilai kepentingan teknik relatif dari karakteristik teknis ini adalah 4.04\% dalam memenuhi kebutuhan pasien secara keseluruhan. Target dari karakteristik teknis ini adalah menciptakan kesejukan dan kenyamanan dalam pelayanan Rumah Sakit harus berusaha menambah AC.

7. Pelayanan yang cepat dan tepat waktu

Pelayanan yang cepat dan tepat waktu mempunyai nilai raw weight sebesar 9.058 dan normalized raw weight sebesar 4.3\%. Hal ini menunjukkan pelayanan yang cepat dan tepat waktu mempunyai nilai tingkat kepentingan secara keseluruhan sebesar $4.3 \%$ dari seluruh keinginan dan kebutuhan pasien. Pelayanan yang cepat dan tepat waktu memiliki prioritas ketujuh dalam keinginan dan kebutuhan pasien yang harus dipenuhi. Karakter teknis yang berperan pada atribut ini yaitu training kesehatan. Target dari karakteristik teknis ini adalah agar profesionalitas pegawai tercapai. RSUD Kabupaten Buleleng harus dapat meningkatkan karakteristik teknik ini agar target yang diharapkan dapat tercapai. Rumah bersalin mampu meningkatkan karakteristik teknik training kesehatan dengan cara setiap ada training atau seminar tentang kesehatan salah satu pegawai dari rumah bersalin dikirim untuk mengikuti seminar tersebut.

8. Tenaga medis yang profesional,

Tenaga medis yang profesional mempunyai nilai raw weight sebesar 9.058 dan normalized raw weight sebesar $4.3 \%$. Hal ini menunjukkan tenaga medis (bidan) yang profesional mempunyai nilai tingkat kepentingan secara keseluruhan sebesar $4.3 \%$ dari seluruh keinginan dan kebutuhan pasien. Tenaga medis yang profesional memiliki prioritas kedelapan dalam keinginan dan kebutuhan pasien yang harus dipenuhi. Karakter teknis yang berperan pada atribut ini yaitu seminar dan training kesehatan. Target dari karakteristik teknis ini adalah agar profesionalitas pegawai tercapai. RSUD Kabupaten Buleleng harus dapat meningkatkan karakteristik teknik ini agar target yang diharapkan dapat tercapai. Rumah sakit mampu meningkatkan karakteristik teknik training kesehatan dengan cara setiap ada raining atau seminar tentang kesehatan salah satu pegawai dari rumah bersalin dikirim untuk mengikuti seminar tersebut. 
9. Ruang parkir yang mamadai dan aman

Ruang parkir yang memadai dan aman mempunyai nilai raw weight sebesar 9.000 dan normalized raw weight sebesar $4.2 \%$. Hal ini menunjukkan ruang parkir yang memadai dan aman mempunyai nilai tingkat kepentingan secara keseluruhan sebesar $4.2 \%$ dari seluruh keinginan dan kebutuhan pasien. Ruang parkir yang memadai dan aman memiliki prioritas kesembilan dalam keinginan dan kebutuhan pasien yang harus dipenuhi. Karakter teknis yang berperan pada atribut ini yaitu perluasan lapangan parkir dan penataan lansekap yang menarik. Target dari karakteristik teknis ini adalah agar parkir yang fungsional tercapai. RSUD Kabupaten Buleleng harus dapat meningkatkan karakteristik teknik ini agar target yang diharapkan dapat tercapai. Rumah sakit mampu meningkatkan karakteristik teknik perluasan lapangan parkir dan penataan lansekap yang menarik dengan cara memanfaatkan lahan yang sisa untuk dibangun tempat parkir.

\section{Analisis Terhadap Karakteristik Teknis}

a. Seminar dan training kesehatan,

Seminar dan training kesehatan mempunyai hubungan yang kuat dan positif dengan kerja sama dengan pihak rumah sakit setempat serta pembinaan moral pegawai. Dengan seminar dan training pegawai kemampuan tenaga medis akan meningkat, sehingga pelayanan dapat ditingkatkan. Seminar dan training kesehatan akan membina tenaga medis yang terikat dengan etika dan peraturanperaturan. Seminar dan training bisa dilaksanakan dengan mengadakan kerja sama dengan rumah sakit atau instansi kesehatan yang lain.

Karakteristik teknik ini juga memiliki hubungan positif dengan komputerisasi sistem administrasi dan arsip, fasilitas stelisator. Sistem komputerisasi administrasi yang berhubungan dengan arsip yang berhubungan dengan medis memerlukan pelatihan atau training, demikian juga pemakaian dan pemanfaatan sterilisator. Karakter teknis ini berperan besar untuk memenuhi atribut atau kebutuhan pasien yaitu tenaga medis yang profesional, pelayanan yang cepat dan tepat waktu. Karakteristik tersebut juga berperan sedang dalam hal perhatian tenaga medis kepada pasien, keramahan dan kesopanan, tindakan sesuai dengan prosedur jaminan pelayanan terhadap pasien yang kesemuanya bisa ditingkatkan dengan jalan seminar dan training kesehatan. Nilai kepentingan teknik relatif dari karakteristik teknis ini adalah $15.26 \%$ dalam memenuhi kebutuhan pasien secara keseluruhan. Target dari karakteristik teknis ini adalah profesionalisme pegawai. Dengan angka kepentingan teknik relatif sebesar $15.26 \%$ menjadikan karakteristik teknik ini menempati prioritas pertama.

b. Kerja sama dengan pihak rumah sakit,

Kerja sama dengan rumah sakit setempat mempunyai hubungan yang 
kuat dengan seminar dan training kesehatan dan layanan purna melahirkan. Karakter ini juga mempunyai korelasi dengan fasilitas sterilisator yang merupakan alat untuk menstrerilkan peralatan medis. Rumah sakit mempunyai SDM dan perlatan yang lebih baik. Seminar dan training bisa dilaksanakan dengan mengadakan kerja sama dengan rumah sakit. Layanan purna melahirkan yang memerlukan penanganan khusus biasanya dirujuk ke rumah sakit.

Karakter teknis ini untuk memenuhi atribut atau kebutuhan pasien yaitu memberikan rasa aman bagi pasien, tersedianya ambulance dengan antar jemput 24 jam. Nilai kepentingan teknik relatif dari karakteristik teknis ini adalah 10.77\% dalam memenuhi kebutuhan pasien secara keseluruhan. Target dari karakteristik teknis ini adalah profesionalisme dan rujukan gawat darurat. Karakteristik teknis ini menempati prioritas kedua.

c. Pelayanan jasa cleaning service,

Karakter teknis ini memiliki hubungan positif dengan karakteristik penambahan lemari dan rak. Dengan penambahan lemari dan rak maka barangbarang dan perabotan pasien akan diletakkan di lemari dan rak. Kebersihan dan kerapian kamar pasien akan terjaga. Sedangkan fasilitas stelisator dan pelayanan cleaning service sama-sama berperan dalam menjaga kesehatan lingkungan agar selalu sehat.

Karakter teknis ini berperan besar untuk memenuhi atribut atau kebutuhan pasien yaitu ruang rawat inap yang bersih dan tersedianya kamar mandi yang bersih dengan nilai numerik 9. Nilai kepentingan teknik relatif dari karakteristik teknis ini adalah $8.61 \%$ dalam memenuhi kebutuhan pasien secara keseluruhan. Target dari karakteristik teknis ini adalah agar kebersihan dan kesehatan lingkungan terjaga. Karakteristik ini harus ditingkatkan agar target yang diharapkan tercapai. Karakteristik teknik ini menempati prioritas ketiga.

d. Pembuatan lapangan parkir dengan tata lansekap yang menarik,

Karakter teknis ini untuk memenuhi kebutuhan ruang parkir yang aman dan memadai, karena realita saat ini kebutuhan parkir belum terpenuhi dengan baik karena belum adanya lapangan parkir. Karakter teknis ini berperan besar untuk memenuhi atribut atau kebutuhan pasien yaitu ruang parkir yang memadai dan aman. Karakteristik teknis juga berperan kuat untuk memenuhi kebutuhan taman agar kelihatan menarik serta berperan sedang dalam memenuhi atribut memberikan rasa aman dalam pelayanan terhadap pasien. Nilai kepentingan teknik relatif dari karakteristik teknis ini adalah 4.73\% dalam memenuhi kebutuhan pasien secara keseluruhan. Target dari karakteristik teknis ini adalah adanya parkir yang fungsional dan tata taman yang menjadi daya tarik. Karakteristik ini perlu diwujudkan agar target yang diharapkan tercapai. Karakteristik teknik ini menempati prioritas keempat. 
e. Pembinaan moral moral pegawai,

Pembinaan moral pegawai mempunyai korelasi yang kuat dan positif dengan seminar dan training kesehatan. Sebagai tenaga harus profesional dan mematuhi kode etik yang telah ditetapkan oleh pihak yang berwenang. Di samping itu juga harus memperhatikan norma-norma kesopanan yang berlaku di masyarakat. Seminar dan training kesehatan bisa ditempuh untuk mewujudkan karakteristik teknik ini. Nilai kepentingan teknik relatif dari karakteristik teknis ini adalah 8.01\% dalam memenuhi kebutuhan pasien secara keseluruhan. Karakteristik teknis ini menempati prioritas kelima.

\section{PENUTUP}

Kesimpulan yang dapat diambil dari penelitian ini adalah kebutuhan dan keinginan pasien terhadap RSUD Kabupaten Buleleng. Dilihat dari pengolahan data yang dilakukan dengan House of Quality dapat diambil beberapa kesimpulan:

1. Atribut-atribut yang merupakan prioritas untuk diperhatikan dan dipenuhi oleh pengelola RSUD Kabupaten Buleleng berdasarkan pembobotan dari masing-masing atribut tersebut, yaitu: ruang rawat inap yang bersih, tempat tidur yang nyaman, kamar mandi yang bersih, tempat ibadah yang bersih, ruang rawat inap yang sejuk dan tenang , ruang parkir yang aman dan memadai, jaminan peralatan medis yang steril, pelayanan yang cepat dan akurat, tenaga medis yang profesional dan ruang parkir yang memadai dan aman.
2. Urutan prioritas tindakan yang harus dilakukan oleh manajemen RSUD Kabupaten Buleleng untuk memenuhi kebutuhan dan keinginan pasien yaitu seminar dan training kesehatan, kerja sama dengan dengan pihak rumah sakit setempat, pelayanan jasa cleaning service, pembuatan lapangan parkir dengan tata lansekap yang menarik, pembinaan moral pegawai dengan pendekatan agama.

\section{DAFTAR PUSTAKA}

Arikunto, Suharsimi, 2002, "Prosedur Penelitian: Suatu Pendekatan Praktek", Rinekha Cipta, Jakarta

Azwar, A., 1996. Pengantar Administrasi Kesehatan. Jakarta: Bina Rupa Aksara

Bendall-Lyon D, Powers TL (2004), “The impact of structure and process attributes on satisfaction and behavioral intentions," International Journal of Service Marketing, Vol 18, Page 114-121

Pamungkas, Wijayanti Dyas. 2006. Pengaruh Harga, Fasilitas dan Kelengkapan Produk terhadap Kepuasan Konsumen Berbelanja di Swalayan Ramai Semarang. Tugas Akhir. Semarang: Universitas Negeri Semarang

Singarimbun, 1989. Metode Penelitian Survey. Edisi Revisi, LP3ES. Jakarta 
Tjiptono, Fandy dan Anastasia Diana, (2003), Total Quality Manajemen, Andi, Yogyakarta.

Tjiptono, Fandy, 2004, Manajemen Jasa, Andi, Yogyakarta
Yamit, Zulian, 2002, "Manajemen Kualitas Produk dan Jasa", Ekonomia, Yogyakarta.

Yamit, Zulian, 2004, Manajemen Kualitas Produk dan Jasa, PT. Ekonomia, Yogyakarta. 